\title{
Microbial biomass and basal respiration of selected Sub-Antarctic and Antarctic soils in the areas of some Russian polar stations
}

\author{
E. Abakumov and N. Mukhametova \\ Department of Applied Ecology, Saint Petersburg State University, 199178, 16-line Vasilyevskiy Island, 29, Russia \\ Correspondence to: E. Abakumov (e.abakumov@bio.spbu.ru)
}

Received: 6 February 2014 - Published in Solid Earth Discuss.: 18 March 2014

Revised: 25 May 2014 - Accepted: 22 June 2014 - Published: 29 July 2014

\begin{abstract}
Antarctica is a unique place for soil, biological, and ecological investigations. Soils of Antarctica have been studied intensively during the last century, when different national Antarctic expeditions visited the sixth continent with the aim of investigating nature and the environment. Antarctic investigations are comprised of field surveys mainly in the terrestrial landscapes, where the polar stations of different countries are situated. That is why the main and most detailed soil surveys were conducted in the McMurdo Valleys, Transantarctic Mountains, South Shetland Islands, Larsemann Hills and the Schirmacher Oasis. Our investigations were conducted during the 53rd and 55th Russian Antarctic expeditions in the base of soil pits, and samples were collected in Sub-Antarctic and Antarctic regions. Sub-Antarctic or maritime landscapes are considered to be very different from Antarctic landscapes due to differing climatic and geogenic conditions. Soils of diverse zonal landscapes were studied with the aim of assessing the microbial biomass level, basal respiration rates and metabolic activity of microbial communities. This investigation shows that Antarctic soils are quite diverse in profile organization and carbon content. In general, Sub-Antarctic soils are characterized by more developed humus (sod) organo-mineral horizons as well as by an upper organic layer. The most developed organic layers were revealed in peat soils of King George Island, where its thickness reach, in some cases, was $80 \mathrm{~cm}$. These soils as well as soils formed under guano are characterized by the highest amount of total organic carbon (TOC), between 7.22 and $33.70 \%$. Coastal and continental Antarctic soils exhibit less developed Leptosols, Gleysols, Regolith and rare Ornhitosol, with TOC levels between 0.37 and $4.67 \%$. The metabolic ratios and basal respiration were higher in SubAntarctic soils than in Antarctic ones, which can be inter-
\end{abstract}

preted as a result of higher amounts of fresh organic remnants in organic and organo-mineral horizons. The soils of King George Island also have higher portions of microbial biomass ( $\max 1.54 \mathrm{mg} \mathrm{g}^{-1}$ ) compared to coastal (max $0.26 \mathrm{mg} \mathrm{g}^{-1}$ ) and continental (max $0.22 \mathrm{mg} \mathrm{g}^{-1}$ ) Antarctic soils. Sub-Antarctic soils differ from Antarctic ones mainly by having increased organic layer thickness and total organic carbon content, higher microbial biomass carbon content, basal respiration, and metabolic activity levels.

\section{Introduction}

Antarctic soils are known for being very diverse in morphology, chemistry, texture and mineralogical composition. Essential pedodiversity within the Antarctic is caused by differences in geographical locations (by latitude) as well as by the existence of so-called Antarctic oases, which are isolated from each other by ice sheets and snow masses (Gilichinsky et al., 2010; Mergelov and Goryachkin, 2010). According to Bockheim and Ugolini (1990), there are three soilclimatic zones in the Antarctic: the Sub-Antarctic zone of tundra or tundra-barren soils (soils of this zone are the most diverse and developed), the zone of the coastal Antarctic, represented by barrens and polar deserts (here the soil diversity is less, and solum consists of $5-10 \mathrm{~cm}$ only), and finally, the zone of real continental Antarctic landscapes, where the soils are quite primitive and even represented by so-called endolithic soils of severe polar deserts (Mergelov and Goryachkin, 2010; Mergelov et al., 2012). The coastal part of the Antarctic exhibits so-called Antarctic oases, i.e., ice- and snow-free terrestrial ecosystems. Tundra ecosystems are typical mainly of maritime or Sub-Antarctic ecosystems, where 
they exhibit plant communities of mosses, lichens, algae and vascular plants - Deschampsia antarctica and Colobantus quitensis. These communities form in relatively humid and warm climates, where there are essential stocks of organic matter in soil horizons and developed soil profiles with an average thickness of about $10-30 \mathrm{~cm}$. Of course, if we compare Antarctic tundras with those from the Arctic zone, they will be very different from each other. The first reason for this is the different component composition of organic plant remnants and different species, and different ecological forms in the polar zones of both hemispheres.

In contrast, the low Antarctic barrens are formed in the absence of vascular plants, and are characterized by severe climatic conditions and mainly forms of consolidated debris or its derivates. Antarctic soils are thus quite different in their profile organization, chemical properties, and organic compound content. It was shown that the total organic carbon (TOC) and organic matter humification degree are quite changeable in soils of different latitudes, which is affected by the humus precursor quality, the thickness of the friable debris, and climatic conditions (Abakumov, 2010b).

In fact, Antarctic soils contain low soil TOC; however, their content is quite different. They vary from zero levels in ahumic regolith soils (Ugolini and Bockheim, 2008; Campbell and Claridge, 1987; Bockheim, 2013) to 3-4\% in soils under mosses, lichens, and cereals (Abakumov, 2010b; Simas et al., 2008), or even to 30-40\% of organic matter in soils formed under guano (Simas et al., 2007). The differences in $\mathrm{C} / \mathrm{N}$ ratios are known to be more sufficient for Antarctic soils, and change from 70 in polar deserts to 2-3 in guano-enriched soils of the maritime Antarctic (Abakumov, 2010b).

TOC is represented not only by colloidal forms of humus (humic and fulvic acids, humin), but there is also an essential portion of detrite forms that provide organic carbon redistribution (Hopkins et al., 2008) or endolitic accumulation of organic matter (Vestal, 1988; Abakumov, 2010b; Mergelov et al., 2012). The humification degrees are differentiated less between the soils of Antarctic zones. The humification index - the ratio of the carbon of humic acids to fulvic acids (Cha / Cfa) - thus belongs to the fulvate (less than 0.5 ) or humate-fulvate (0.5-1.0) type. There is therefore no high intensity of humification or organic matter transformation in these polar soils, but we can expect essential differences caused by local conditions differing from geographical climatic gradients.

Previous works analyzed changes of microbial biomass and respiration rates along the geographical gradient of polar regions. It was shown that metabolical activity is relatively higher in Sub-Antarctic soils in comparison to continental soils (Gilichinsky et al., 2010). According to Yoshitake et al. (2007), carbon (C) and nitrogen (N) content are not considered limiting factors to heterotrophic respiration in high Arctic soils. Kumar et al. (2013) suggested that changes in soil temperature were not critically affecting Arctic soils.
According to Dennis et al. (2013), the effect of the warming on the soil microbial community is expected to be different for soils of Sub-Antarctic and Antarctic landscapes. Soil respiration has been predicted by organic phosphorous and total nitrogen content in Sub-Antarctic soils for habitat comparison (Lubbe and Smith, 2012). Latitudinal research of different Antarctic soils shows that the temperature sensitivity of microorganisms increases with mean annual soil temperature, suggesting that bacterial communities from colder regions were less temperature sensitive than those from the warmer regions (Rinnan et al., 2009). We can thus summarize that there are essential changes in soil microbial activity between real Antarctic soil at high latitudes and maritime Sub-Antarctic soils. These differences are caused by the temperature sensitivity of organisms, different enzymatic activity, and different pools of $\mathrm{C}, \mathrm{N}$ and $\mathrm{P}$. Soil basal respiration and biological activity data are very poor or absent for soils of different climatic zones in the Antarctic. These data are important for soil carbon turnover modeling, for simulation of greenhouse gases emissions and soil organic dynamics under conditions of a changing climate. That is why the aim of our investigation is to compare the microbiological activity in soils of three latitude zones of the Antarctic from places near Russian polar Antarctic stations. To achieve this aim, the following objectives were formulated:

1. To identify soil types and chemical characteristics in the studied areas.

2. To determine and interpret the values of soil respiration, microbial biomass and metabolic quotients in different climatic and vegetation zones of the Antarctic.

\section{Materials and methods}

\subsection{Study site}

The study sites were situated in different climatic regions of the Antarctic: Russkaya valley (Marie Byrd Land), Larsemann Hills (Princess Elizabeth Land), and King George Island (South Shetlands archipelago, Antarctic Peninsula). These plots represent the coastal-continental Antarctic, the coastal Antarctic and Sub-Antarctic climatic regions, respectively. Some data on soil diversity and its features were published by Vlasov et al. (2005), Lupachev and Abakumov (2013), Gilichiskiy et al. (2010), Mergelov and Goryachkin (2010), Simas et al. (2007, 2008), Abakumov et al. (2013) and others. Climatic conditions are quite different in all plots investigated. The most severe conditions are at the Russkaya station, while King George Island is characterized by the warmest and most humid conditions.

Russkaya station ( $\mathrm{R})$ is situated on the Berks peninsula, Marie Byrd Land, western Antarctic, $74^{\circ} 46^{\prime} \mathrm{S}, 136^{\circ} 48^{\prime} \mathrm{W}$. The annual temperature, precipitation, and maximal wind velocity are $-12.4^{\circ} \mathrm{C}, 2000 \mathrm{~mm}$, and $77 \mathrm{~ms}^{-1}$, respectively. 
Basalts, granites and gneisses are the main components of the bedrock composition (Lupachev and Abakumov, 2013). Plant cover is comprised mostly of lichens, mosses and some algae, while they vegetate on the former penguin rockeries.

Progress station is situated on the coast of the Larsemann Hills (L), Princess Elizabeth Land, eastern Antarctic, $69^{\circ} 30^{\prime} \mathrm{S}, 76^{\circ} 19^{\prime} \mathrm{E}$. The annual temperature is $-9.8^{\circ} \mathrm{C}$, and the mean wind velocity is $6.7 \mathrm{~ms}^{-1}$, with a maximum of about $53 \mathrm{~ms}^{-1}$. The annual precipitation is about $250 \mathrm{~mm}$.

The Bellingshausen station belongs to the Fildes peninsula, King George Island (KGI), $62^{\circ} 12^{\prime} \mathrm{S}, 58^{\circ} 58^{\prime} \mathrm{W}, 40 \mathrm{~m}$ about sea level (a.s.l.). The parent material is comprised of andesite, basalt, and tuffs. The coastal areas are covered by maritime sands and gravels, and moraines and some fluvioglacial materials cover the periglacial plots (Peter et al., 2008). The mean annual air temperature is $-2.8^{\circ} \mathrm{C}$. During the Australian summer (January and February), the mean monthly temperature rises to $5-6{ }^{\circ} \mathrm{C}$ on soil humus horizons (Abakumov and Andreev, 2011). The total annual precipitation reaches $729 \mathrm{~mm}$, and the number of days with precipitation varies from 22 to 30 days per month. The wind velocity is $9.3 \mathrm{~m} \mathrm{~s}^{-1}$ (Peter et al., 2008), with a maximum of about $28 \mathrm{~m} \mathrm{~s}^{-1}$. The Fildes peninsula exhibits a diverse variety of plant species (Abakumov, 2010b). Mono-species plant communities are just as common as mixed ones, both in the coastal part and on the plateau of the peninsula. Many authors therefore identify them as tundra or Antarctic tundra (Casanov-Kathny and Cavieres, 2012; Parnikoza et al., 2011; Bölter et al., 1997), because if compared to the Northern Hemisphere, this should be classified as some intermediate between tundra and barrens. In any case, the plant communities of King George Island are the most developed and richest throughout the Antarctic.

An indicator of biological activity within soils is the number of days where soil temperature is above zero. This value was 12-20 days on the R plot, 30-40 days on the Progress plot, and a maximum of 90 days at the Bellingshausen station (as is estimated by in situ termochrone loggers of humus horizons for one year). This index of biological activity is critical for mineralization and humification processes, and is different in diverse zones of the Antarctic. The KGI thus belongs to the Sub-Antarctic region, while the $\mathrm{R}$ and $\mathrm{L}$ plots are classified as the coastal region of the real Antarctic.

\subsection{Soil sampling}

The sampling of the soils and the organic layers was conducted during the 53rd Russian Antarctic expedition (RAE) from 14 January 2008 to 25 February 2008 (samples from $\mathrm{R}$ ), and during the 55th RAE from 4 December 2008 to 12 February 2010 (samples from KGI and L) on the "Academician Fedorov" scientific vessel. Soil descriptions had been partly published previously (Abakumov et al., 2008; Abakumov, 2010a, b). Briefly, soils of King George Island are comprised of Gleysols, Crysols, Leptosols and Lithosols, as well as one profile of Peat soils. Soil of the L plot were Gleysols on the lake coasts and exhibited one example of the so-called Regolith or "ahumic soils" according to Tedrow and Ugolini (1966). Regolith and Leptosols were typical of the landscape of the R plots. At least three individual samples were taken from each horizon of the soil profile. The areas of the soil pit were more or less the same for all studied plots, but differed for KGI, where soil polypedons were more or less uniform in space, and for $\mathrm{R}$ and $\mathrm{L}$ plots, where soil areas were isolated from each other due to inhomogenous vegetation distribution and non-regular soil cover character. All samples were collected during the Australian summer. Three soil samples were put into special containers with volumes of about $200 \mathrm{~cm}^{3}$. Each sample replication was about $50 \mathrm{~g}$ of filed moisture weight. In some cases, while the fine earth content was too low, we collected only 10 to $15 \mathrm{~g}$ of soil to determine the general soil properties. The samples were stored in a freezer on the vessel to prevent transformation processes. The samples were then stored at $0^{\circ} \mathrm{C}$ in the laboratory before the analyzing procedures. Weather conditions during the sampling were comparable for all the plots investigated: sunny weather, no precipitation, and the temperature was approximately $3-8^{\circ} \mathrm{C}$. This allows us to suggest that the microbial respiration status of the microbial community was more or less the same for all the plots investigated.

\subsection{Laboratory analyses}

Soil samples, after being transported from the scientific vessel to the laboratory, were air dried in Petri cups, then grounded and sieved through the sieve with a diameter of $2 \mathrm{~mm}$. It was not possible to avoid drying, because only the dry soil can be homogenized, which is very important for sandy or coarsely textured soils of the Antarctic. The soil color was determined with the use of the Munsell color chart in the laboratory of the scientific vessel. The TOC was determined for air-dried soil by wet combustion in a solution of potassium dichromate in sulfuric acid (the Tyurin or Walkley-Black method) (Walkley, 1935). The nitrogen content was assessed by the Kjeldahl method. The carbon content of the microbial biomass ( $\mathrm{Cmic}$ ) was determined in field moist samples with the chloroform fumigation-extraction method. The field moisture of soils was determined in the laboratory as the weight of the water saturate soil sample minus the weight of the air-dried soil. The hygroscopic water levels were determined by soil drying at $105^{\circ} \mathrm{C}$ and further soil weighting. The fine earth portions were determined by weighting on soil remnants after sieving through the $2 \mathrm{~mm}$ sieve.

A total of $5 \mathrm{~g}$ of soil was fumigated in chloroform following extraction of dissolved organic matter (DOC) by $0.5 \mathrm{M} \mathrm{K}_{2} \mathrm{SO}_{4}$, and filtration and evaluation of the DOC portion by the dichromate method. The DOC of the control samples was determined in extracts without fumigation. Soil basal respiration (BR) was evaluated in laboratory closed 
Table 1. Morphological features and chemical characteristics of Antarctic soils. \pm means the standard deviation.

\begin{tabular}{|c|c|c|c|c|c|c|c|}
\hline Soil & Horizon & $\begin{array}{l}\text { Depth } \\
\mathrm{cm}\end{array}$ & Color & $\begin{array}{l}\text { TOC } \\
(\%)\end{array}$ & $\begin{array}{l}\text { Hygroscopic } \\
\text { water } \\
(\%)\end{array}$ & $\begin{array}{l}\mathrm{pH} \text { in } \\
\text { water }\end{array}$ & $\begin{array}{l}\text { Fine } \\
\text { earth } \\
(\%)\end{array}$ \\
\hline Leptosol, R & $\mathrm{W}$ & $0-7$ & $10 \mathrm{YR} 5 / 3$ & $4.67 \pm 0.23$ & $2.58 \pm 0.014$ & 5.90 & $\mathrm{Nd}$ \\
\hline Post-Ornithosol, R & $\mathrm{O}$ & $0-10$ & $10 \mathrm{YR} 5 / 3$ & $0.60 \pm 0.03$ & $2.41 \pm 0.08$ & 5.80 & 11 \\
\hline Regolith, R & $\begin{array}{l}\mathrm{C}_{1} \\
\mathrm{C}_{2}\end{array}$ & $\begin{array}{l}2-15 \\
15-30\end{array}$ & $\begin{array}{l}5 \mathrm{YR} 6 / 1 \\
5 \mathrm{YR} 6 / 1\end{array}$ & $\begin{array}{l}0.52 \pm 0.03 \\
0.87 \pm 0.05\end{array}$ & $\begin{array}{l}1.00 \pm 0.08 \\
1.98 \pm 0.15\end{array}$ & $\begin{array}{l}5.40 \\
3.30\end{array}$ & $\begin{array}{l}5 \\
9\end{array}$ \\
\hline Regolith, L & $\begin{array}{l}\mathrm{C}_{1} \\
\mathrm{C}_{2}\end{array}$ & $\begin{array}{l}0-10 \\
10-20\end{array}$ & $\begin{array}{l}5 \text { YR 6/1 } \\
5 \text { YR 6/1 }\end{array}$ & $\begin{array}{l}0.08 \pm 0.01 \\
0.05 \pm 0.01\end{array}$ & $\begin{array}{l}0.22 \pm 0.01 \\
0.31 \pm 0.02\end{array}$ & $\begin{array}{l}6.39 \\
7.77\end{array}$ & $\begin{array}{l}7 \\
16\end{array}$ \\
\hline $\begin{array}{l}\text { Gleysol, coast of } \\
\text { Steppet lake, L }\end{array}$ & $\begin{array}{l}G \\
G\end{array}$ & $\begin{array}{l}0-2 \\
2-8\end{array}$ & $\begin{array}{l}7,5 \text { YR } 6 / 1 \\
5 \text { YR } 6 / 1\end{array}$ & $\begin{array}{l}1.22 \pm 0.05 \\
0.83 \pm 0.09\end{array}$ & $\begin{array}{l}0.36 \pm 0.02 \\
0.41 \pm 0.03\end{array}$ & $\begin{array}{l}3.57 \\
5.70\end{array}$ & $\begin{array}{l}53 \\
26\end{array}$ \\
\hline $\begin{array}{l}\text { Gleysol, coast of } \\
\text { Reid lake, L }\end{array}$ & $\begin{array}{l}\mathrm{C}_{\mathrm{ox}} \\
\mathrm{G}\end{array}$ & $\begin{array}{l}0-12 \\
12-20\end{array}$ & $\begin{array}{l}5 \mathrm{YR} 6 / 2 \\
5 \mathrm{Y} 4 / 4\end{array}$ & $\begin{array}{l}0.37 \pm 0.04 \\
0.50 \pm 0.06\end{array}$ & $\begin{array}{l}0.23 \pm 0.01 \\
0.33 \pm 0.02\end{array}$ & $\begin{array}{l}6.80 \\
7.04\end{array}$ & $\begin{array}{l}28 \\
21\end{array}$ \\
\hline Lithosol, KGI & $\begin{array}{l}\mathrm{O} \\
\mathrm{O} \\
\mathrm{C}\end{array}$ & $\begin{array}{l}0-3 \\
3-6 \\
6-15\end{array}$ & $\begin{array}{l}10 \text { YR 5/3 } \\
5 \text { YR 6/1 } \\
5 \text { YR 6/1 }\end{array}$ & $\begin{array}{l}6.34 \pm 0.19 \\
1.73 \pm 0.07 \\
0.80 \pm 0.07\end{array}$ & $\begin{array}{l}6.34 \pm 0.25 \\
4.73 \pm 0.15 \\
-\end{array}$ & $\begin{array}{l}5.60 \\
6.50 \\
6.60\end{array}$ & $\begin{array}{l}\mathrm{Nd} \\
18 \\
34\end{array}$ \\
\hline Lithosol, KGI & $\begin{array}{l}\mathrm{O} \\
\mathrm{O} \\
\mathrm{C}\end{array}$ & $\begin{array}{l}0-3 \\
3-13 \\
13-21\end{array}$ & $\begin{array}{l}10 \mathrm{YR} 4 / 2 \\
10 \mathrm{YR} 5 / 2 \\
5 \mathrm{YR} 6 / 1\end{array}$ & $\begin{array}{l}11.25 \pm 0.45 \\
1.20 \pm 0.04 \\
0.95 \pm 0.09\end{array}$ & $\begin{array}{l}9.00 \pm 0.74 \\
4.66 \pm 0.25 \\
7.42 \pm 0.32\end{array}$ & $\begin{array}{l}4.74 \\
6.10 \\
4.85\end{array}$ & $\begin{array}{l}\mathrm{Nd} \\
56 \\
56\end{array}$ \\
\hline Organic Gleysol, KGI & $\mathrm{O}$ & $0-3$ & $10 \mathrm{YR} 4 / 2$ & $14.02 \pm 0.74$ & $8.41 \pm 0.12$ & 6.33 & $\mathrm{Nd}$ \\
\hline Peat soil, KGI & $\mathrm{O}$ & $0-20$ & 7,5 YR 5/6 & $33.7 \pm 0.98$ & $9.57 \pm 0.58$ & 5.25 & $\mathrm{Nd}$ \\
\hline Ornhitosol, KGI & Ocopr & $0-10$ & $2,5 \mathrm{YR} 4 / 4$ & $7.56 \pm 0.12$ & $0.65 \pm 0.04$ & 6.01 & $\mathrm{Nd}$ \\
\hline Ornhitic Leptosol, KGI & Ocopr & $0-10$ & $2,5 \mathrm{YR} 4 / 4$ & $7.22 \pm 0.21$ & $13.25 \pm 0.85$ & 7.30 & 9 \\
\hline Leptosol, KGI & $\mathrm{W}$ & $0-5$ & $10 \mathrm{YR} 5 / 3$ & $1.32 \pm 0.05$ & $0.75 \pm 0.04$ & 5.40 & 47 \\
\hline
\end{tabular}

chambers by $\mathrm{CO}_{2}$ concentrations in an alkaline solution that was saved in a plastic container during the incubation process for 10 days. A metabolical quotient was calculated as the ratio of respiration $\mathrm{C}-\mathrm{CO}_{2}$ to $\mathrm{Cmic}$ per day of incubation (Jenkinson and Powlson, 1976; Vance et al., 1987). We have determined the soil microbiological characteristics on all soil horizons, where the soil amount was enough. In some cases, we were limited to general soil analyses because the soil sample amount was not enough for microbiological investigation. While the soil respiration and microbial biomass were measured in the described laboratory conditions, data obtained in this experiment cannot be interpolated directly to field conditions, but can only be used for a comparison of soil microbiological activity in the same experimental conditions (temperature $20^{\circ} \mathrm{C}$, moisture $60 \%$ to initial soil weight).

\subsection{Statistical analyses}

Data obtained were analyzed statistically with the SIGMAPLOT 8.0 program (mean values, paired $t$ test, one-way Anova). The normality of the data was assesed using a parametric test. Ranks of data for Sub-Antarctic and
Antarctic soils were compared to determine if there were statistical differences in soil formed under different climatic conditions. Significant differences were considered to exist when $P<0.05$. No differences between soil horizons and their depth were assessed, while the number of soil samples was not enough to conduct this type of comparison.

\section{Results and discussion}

\subsection{Soil morphology}

All the soils investigated were identified on the type level - mainly according to WRB (2006) - and were considered to be weakly developed soils without evident differentiation into horizons (Fig. 2, Table 1). These soils are typical representatives of Leptosols at the R plot and KGI, ahumic soils of Regoliths at the R and L plots, Lithosols on KGI and PostOrhnitosol (R) and current ("active") Orhnitosol (KGI). Permanent and temporarily over-moisted soils with some redoximorphic features of gleyification were characteristics of the L plot. 


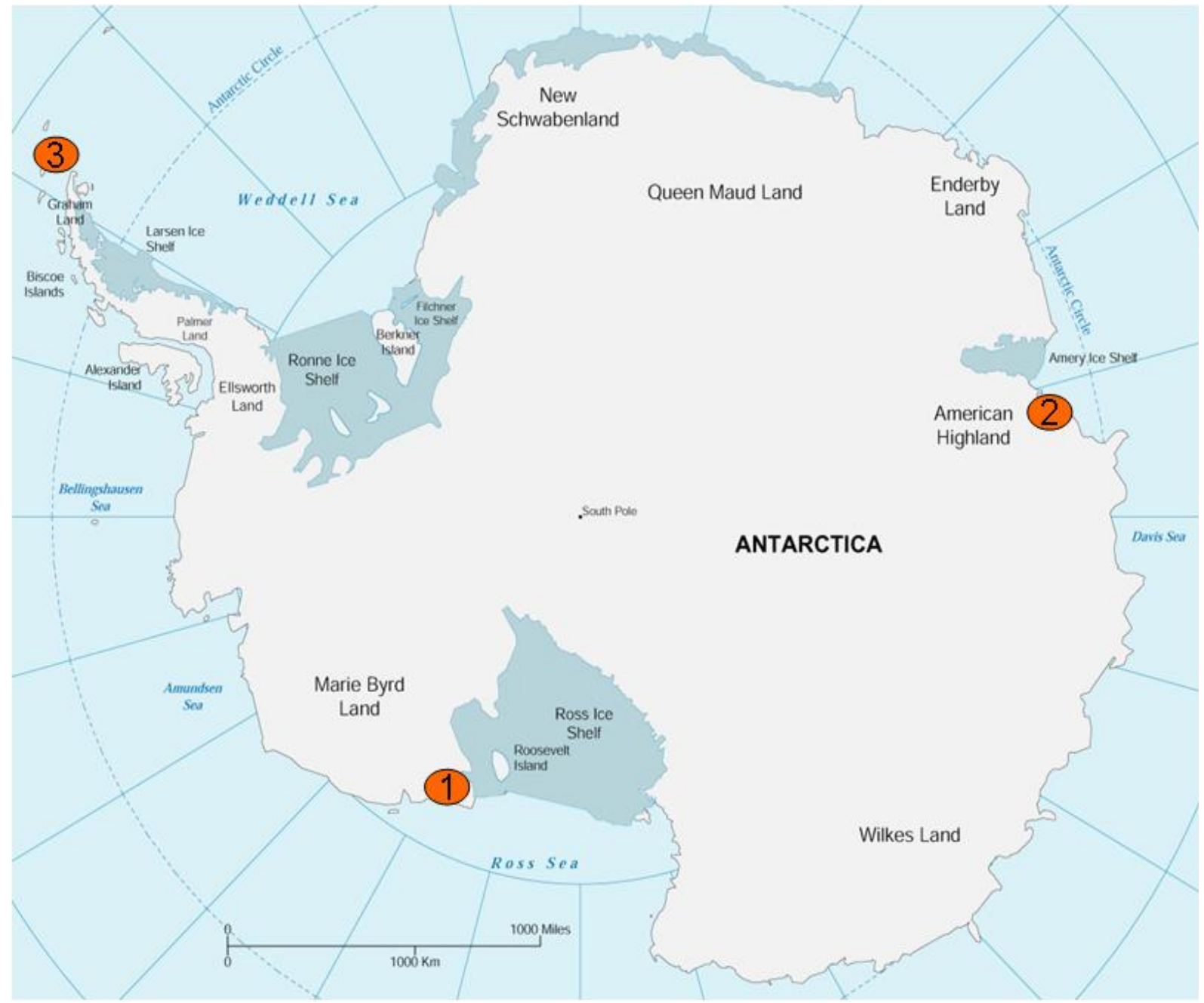

Figure 1. Study areas in the Antarctic: 1 - Russkaya station, 2 - Larsemann hills, 3 - King George Island.

Regoliths did not show any morphological evidence of humus accumulation and were represented by slightly different layers of mineral materials. Gleysols were determined on the basis of the gray-blue color of the mineral part: in the upper part of solum they had an organic or organomineral grayish horizon. Leptosols are described mostly under the lichens and mosses on the dense bedrocks. Ornhitosols (Fig. 1) should be divided into two categories: those that are currently occupied by penguins, and those that are the former penguin rockeries, now invaded by birds. We will call the latter Post-Orhnitosols.

\subsection{Carbon content and general soil properties}

Soil color, in general, was related to two factors: the degree of soil organic matter transformation and the degree of Gleyic process development. The intensity of the gray-brown color increased from organic to humus horizons. Most of the soil samples investigated were characterized by acid to neutral
$\mathrm{pH}$ values; only the fine earth of the Regolith $\mathrm{C}_{2}$ horizon (L) had a slightly alkaline $\mathrm{pH}$, which can be interpreted as the result of a non-intensive base leaching process.

The soils investigated contained different amounts of organic carbon content. TOC values ranged from 0.05 to $1.22 \%$ in soils of the L site, to 4 to $7 \%$ in organo-mineral horizons of the KGI soil, and to more than $30 \%$ in peat (turf) material (Table 2). The differences in carbon values and absorbed water were statistically significant for Sub-Antarctic and Antarctic soils: $P<0.03$ and $P<0.01$ by $t$ test, respectively. One-way Anova tests showed the same differences, with $P$ levels of $P<0.01$ and $P<0.03$ for TOC and hygroscopic water. The lowest organic carbon content was fixed for Regolith soil, which is not really soil, but so-called "ahumic" soil according to Tedrow and Ugolini (1966). These ahumic soil-like bodies contain nearly entirely mineral compounds and only very small portions of organic components, and were presented and described in the Larsemann Hills oasis. Ahumic soils are typical of severe landscapes, where soil 
Table 2. Microbial biomass, basal respiration, and metabolical quotient in soils. \pm means the standard deviation.

\begin{tabular}{|c|c|c|c|c|}
\hline Soil & Horizon & $\begin{array}{c}\text { Cmic } \\
\left(\mathrm{mg} \mathrm{g}^{-1}\right)\end{array}$ & $\begin{array}{c}\text { Basal } \\
\text { respiration } \\
\left(\mathrm{mg} \mathrm{g}^{-1} \text { day }^{-1}\right)\end{array}$ & $\begin{array}{c}\text { Metabolical } \\
\text { quotient }\end{array}$ \\
\hline Leptosol, R & $\mathrm{W}$ & $0.11 \pm 0.01$ & $0.006 \pm 0.001$ & $0.06 \pm 0.001$ \\
\hline Post-Ornithosol, R & $\mathrm{O}$ & $0.17 \pm 0.01$ & $0.011 \pm 0.002$ & $0.07 \pm 0.001$ \\
\hline Regolith, R & $\begin{array}{l}\mathrm{C}_{1} \\
\mathrm{C}_{2}\end{array}$ & $\begin{array}{l}0.11 \pm 0.01 \\
0.22 \pm 0.02\end{array}$ & $\begin{array}{l}0.006 \pm 0.001 \\
0.012 \pm 0.001\end{array}$ & $\begin{array}{l}0.06 \pm 0.001 \\
0.06 \pm 0.001\end{array}$ \\
\hline Regolith, L & $\begin{array}{l}\mathrm{C}_{1} \\
\mathrm{C}_{2}\end{array}$ & $\begin{array}{l}0.26 \pm 0.02 \\
0.14 \pm 0.02\end{array}$ & $\begin{array}{l}0.005 \pm 0.001 \\
0.020 \pm 0.003\end{array}$ & $\begin{array}{l}0.02 \pm 0.002 \\
0.14 \pm 0.005\end{array}$ \\
\hline $\begin{array}{l}\text { Gleysol, coast of } \\
\text { Steppet lake, L }\end{array}$ & $\begin{array}{l}\mathrm{G} \\
\mathrm{G}\end{array}$ & $\begin{array}{l}0.20 \pm 0.03 \\
0.20 \pm 0.02\end{array}$ & $\begin{array}{l}0.004 \pm 0.001 \\
0.014 \pm 0.001\end{array}$ & $\begin{array}{l}0.02 \pm 0.001 \\
0.07 \pm 0.002\end{array}$ \\
\hline $\begin{array}{l}\text { Gleysol, coast of } \\
\text { Reid lake, L }\end{array}$ & $\begin{array}{l}\mathrm{C}_{\mathrm{ox}} \\
\mathrm{G}\end{array}$ & $\begin{array}{l}0.23 \pm 0.02 \\
0.17 \pm 0.01\end{array}$ & $\begin{array}{l}0.014 \pm 0.001 \\
0.002 \pm 0.000\end{array}$ & $\begin{array}{l}0.06 \pm 0.004 \\
0.01 \pm 0.002\end{array}$ \\
\hline Lithosol, KGI & $\begin{array}{l}\mathrm{O} \\
\mathrm{O}\end{array}$ & $\begin{array}{l}0.49 \pm 0.03 \\
0.16 \pm 0.01\end{array}$ & $\begin{array}{l}0.060 \pm 0.003 \\
0.010 \pm 0.001\end{array}$ & $\begin{array}{l}0.10 \pm 0.003 \\
0.06 \pm 0.005\end{array}$ \\
\hline Lithosol, KGI & $\begin{array}{l}\mathrm{O} \\
\mathrm{O}\end{array}$ & $\begin{array}{l}1.20 \pm 0.05 \\
0.23 \pm 0.01\end{array}$ & $\begin{array}{l}0.100 \pm 0.007 \\
0.003 \pm 0.001\end{array}$ & $\begin{array}{l}0.08 \pm 0.005 \\
0.01 \pm 0.002\end{array}$ \\
\hline Organic Gleysol, KGI & $\mathrm{O}$ & $0.41 \pm 0.02$ & $0.040 \pm 0.003$ & $0.10 \pm 0.003$ \\
\hline Peat soil, KGI & $\mathrm{O}$ & $1.54 \pm 0.09$ & $0.080 \pm 0.006$ & $0.05 \pm 0.001$ \\
\hline Ornhitosol, KGI & Ocopr & $0.92 \pm 0.07$ & $0.050 \pm 0.002$ & $0.05 \pm 0.004$ \\
\hline Ornhitic Leptosol, KGI & Ocopr & $0.74 \pm 0.06$ & $0.090 \pm 0.004$ & $0.12 \pm 0.005$ \\
\hline Leptosol, KGI & $\mathrm{W}$ & $0.34 \pm 0.04$ & $0.009 \pm 0.002$ & $0.03 \pm 0.004$ \\
\hline
\end{tabular}

formation is limited by low organic matter production. At the same time, there are soils with essentially higher portions of carbon in this Antarctic oasis. These soils were classified as Gleysols, i.e., soils covered seasonally by water. Then, at the end of the Australian summer, they were within a sub-areal environment. These soils were called "seasonal amphibious soils" (Abakumov and Krylenkov, 2011). Soil organic carbon content values in soils of KGI were comparable to those that have been published previously (Abakumov, 2010b; Zhao, 2000). The organic carbon values agree well with the absorbed water levels. This is very important for soils that are known as soils with a low and fine earth content (Abakumov, 2010b; Campbell and Claridge, 1987). All the soils investigated are mostly slightly acidic; there are no alkaline layers between them due to the absence of the effect of ocean salt accumulation and because of acid or neutral composition of the parent materials. There were also no statistical differences between the soils investigated. The fine earth content in general is essentially higher in the soils of KGI compared to soils of the continental oasis $(P<0.04)$, due to a different intensity of weathering (Vlasov et al., 2005) and the genesis of the underlying bedrocks (Peter et al., 2008).
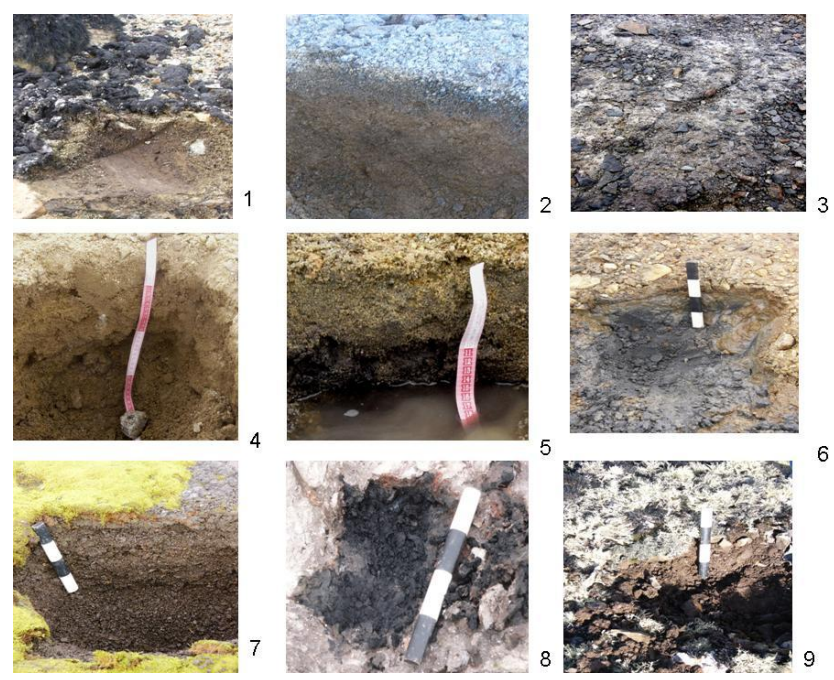

Figure 2. Photos of selected soils. R: 1 - Leptosol, 2 - Regolith, 3 post-Ornhitosol surface. L: 4 - Regolith, 5 - Gleysol, Steppet lake, 6 - seasonal Gleysol, Reid lake. K: 7 - Lithosol, 8 - Orhnitosol, 9 - Leptosol. 


\subsection{Microbiological characteristics of soils}

The differences between Sub-Antarctic and Antarctic soils in carbon content, soil microbial biomass, and basal respiration were statistically significant $(P<0.01$ for all indexes by both $t$ test and one-way Anova methods). The values for microbial biomass carbon were generally the highest in Sub-Antarctic soils of KGI, especially in the upper organic horizons in comparison to soils of coastal Antarctic landscapes $(\mathrm{L}, \mathrm{R})$. The same trend was found for basal respiration of soils. The metabolic soil activity was higher in Sub-Antarctic soils, which can be interpreted as higher numbers of fresh organic remnants on well-developed organic horizons. Metabolic ratios were sufficiently less in soils of oases in the coastal Antarctic. This could be explained as a result of more severe climatic conditions as well as by a more homogenous composition of organic remnants with simultaneously decreased total organic carbon content. Two soils (Regolith and one of Gleysols) within the L plot showed more decreased metabolic ratios in the upper layers than in the deeper layers. By contrast, the second Gleysol of this oasis shows a controversial distribution of these values, which can be explained by the development of oxidation processes on the Gox (gleyic redoximorphic) horizon. These soils are so-called seasonal or amphibious soils (Abakumov and Krylenkov, 2011), where the sub-aquatic condition changes by air exposed at the end of the Australian summer. This is the reason for the intensification of the microbial processes in the upper solum. Levels of microbial biomass were essentially less in $\mathrm{R}$ soils due to more severe climatic conditions. The metabolic ratios were less variable in soils near the $\mathrm{R}$ plot than in the case of the L study site.

We summarize that soils of different Antarctic zones have different levels of carbon content, basal respiration, and metabolic quotient. The most homogenous group is made up of the soils near the $\mathrm{R}$ study site. This station had the most severe climate. Furthermore, the diversity of the soils as well as the diversity of the climatic conditions increase to the north. This results in an increasing variability of microbial community characteristics and the rate of total organic matter accumulations. Our data thus confirm the hypothesis of Rinnan et al. (2009) that there are geographical trends in microbial community sensitivity in latitudinal sequences in Antarctica. They also agree well with previously published data on the metabolic activity of the Sub-Antarctic and Antarctic (Gilichinsky et al., 2010). Not only chemical properties of soil affect soil respiration levels (Lubbe and Smith, 2012); climatic conditions do too (temperature and soil moisture). This was especially important for comparing the level of basal respiration in standardized laboratory conditions for soils from different natural zones (this gives us an opportunity to compare soils of different climates under the same experimental conditions), but not in a field, while the climatic conditions of the expedition route were different. Our data show that annual temperatures, periods of above- zero temperature, and levels of precipitation may play roles in levels of soil biological activity. Previously it was shown (Smith, 2003) that changing temperatures from 5 to $20^{\circ} \mathrm{C}$ does not essentially affect soil respiration. We suppose that this is possible in the case of analyzing soil on one island or in one oasis. While comparing soils of different natural zones, these differences should be more apparent, and our data have shown these results.

\section{Conclusions}

Soils of diverse Antarctic landscapes were investigated to assess the microbial biomass level, basal respiration rates, and metabolic activity of microbial communities. The investigation shows that Antarctic soils are quite different in profile organization and carbon content. In general, SubAntarctic soils are characterized by more developed humus (sod) organo-mineral horizons and by an upper organic layer. The most developed organic layers were revealed in the peat soils of KGI, where soil thickness reaches $80 \mathrm{~cm}$. These soils as well as soils under guano is characterized by the highest amount of organic carbon. Coastal and continental Antarctic soils are comprised of less developed Leptosols, Gleysols and Regolith, with some Ornhitosol as well. In general, organic carbon content is less in Antarctic soils than in SubAntarctic soils. The metabolic activity and basal respiration were higher in Sub-Antarctic soils than in Antarctic soils, due to higher amounts of fresh organic remnants on organic and organo-mineral horizons. The soils of KGI also contain higher portions of microbial biomass than coastal and continental Antarctic soils. These data support the conclusions that Sub-Antarctic soils differ from Antarctic soils in increased thickness of organic layers and total organic carbon content, higher microbial carbon content, basal respiration, and metabolic activity levels. This short assessment of biogenic processes thus shows that geographical trends can cause changes in organic matter transformation indexes.

Acknowledgements. This work was supported by the Russian foundation for basic research, projects 12-04-00680-a, 13-04-00843-a, 13-04-90411 ukr-f-a and by Saint-Petersburg State University research grant 1.37.151.2014. The authors thank V. Lukin, head of the Russian Antarctic expedition, H.-U. Peter and MSc Matthias Kopp, Jena University, for help in the transportation of soil samples from Antarctica to Saint Petersburg, and A. Lupachev, Institute of Physico-chemical and biological problems of soil science RAS, for soil photos nos. 2-6 and 2-8.

Edited by: P. Pereira 


\section{References}

Abakumov, E. V.: Particle-size distribution in soils of West Antarctica, Eur. Soil Sci., 43, 297-304, 2010 a.

Abakumov, E. V.: The sources and composition of humus in some soils of West Antarctica, Eur. Soil Sci., 43, 499-508, 2010 b.

Abakumov, E. V. and Andreev, M. P.: Temperature regime of humus horizons of soil of King-George Island, Western Antarctic, Transactions of Saint-Petersburg University, Ser. 3, 2, 129-133, 2011.

Abakumov, E. V. and Krylenkov, V. A.: Soil of Antarctic, Priroda, 3, 58-62, 2011.

Abakumov, E. V., Pomelov, V. N., Vlasov, D. Y., and Krylenkov, V. A.: Morphological organization of soils in Western Antarctica, Vestn. St.-Peterb. Univ., Ser. 3, Biol., 3 102-115, 2008 (in Russian).

Abakumov, E. V., Gagarina, E. I., Sapega, V. F., and Vlasov, D. Yu.: Micromorphological Features of the Fine Earth and Skeletal Fractions of Soils of West Antarctica in the Areas of Russian Antarctic Stations, Eur. Soil Sci., 46, 1219-1229, 2013.

Bockheim, J. G.: Paleosols in the Transantarctic Mountains: indicators of environmental change, Solid Earth, 4, 451-459, doi:10.5194/se-4-451-2013, 2013.

Bockheim, J. G. and Ugolini, F. C.: A review of pedogenic zonation in well-drained soils of the southern circumpolar region, Quaternary Res., 34, 47-66, 1990.

Bölter, M., Blume, H.-P., Schneider, D., and Beyer, L.: Soil properties and distributions of invertebrates and bacteria from KingGeorge Island (Arctowskiy station), Maritime Antarctic, Polar Biol., 18, 295-394, 1997.

Campbell, I. B. and Claridge, G. G. C.: Antarctica: Soils, Weathering Processes and Environment, Elsevier, Amsterdam, 1987.

Casanov-Kathny, M. A. and Cavieres, L. A.: Antarctic moss carpets facilitate growth of Deschampsia Antarctica but not its survival, Polar Biol., 35, 1869-1878, 2012.

Dennis, P. G., Newsham, N. K., Rushton, S. P., Ord, V. J., O'Donnell, A. G., and Hopkins, D. W.: Warming constrains bacterial community responses to nutrient inputs in a southern, but not northern, maritime Antarctic soil, Soil. Biol. Biochem., 57, 248-255, 2013.

Gilichinsky, D., Abakumov E., Abramov, A., Fyodorov Davydov, D., Goryachkin, S., Lupachev, A., Mergelov, N., and Zazovskaya, E.: Soils of Mid and Low Antarctic: diversity, geography, temperature regime, World Congress of Soil Science, Soil Solutions for a Changing World, 1-6 August 2010, Brisbane, Australia, Published on DVD, 2010.

Hopkins, D. W., Sparrow, A. D., Gregorich, E. G., Novis, P., Elbering, B., and Greenfield, L. G.: Redistibuted lacustrine detritus as a spatial subsidy of biological resources for soils in an Antarctic dry valley, Geoderma, 144, 86-92, 2008.

Jenkinson, D. S. and Powlson, D. S.: The effects of biocidal treatment on metabolism in soil. V. A method for measuring soil biomass, Soil Biol. Biochem., 8, 209-213, 1976.

Kumar, N., Grogan, P., Chu, H., Christiansen, C. T., and Walker, V. K.: The Effect of Freeze-Thaw Conditions on Arctic Soil Bacterial Communities, Biology, 2, 356-377, 2013.

Lubbe, A. and Smith, R. V.: Field Soil Respiration Rate on a SubAntarctic Island: Its Relation to Site Characteristics and Response to Added C, N and P, Open J. Soil Sci., 2, 187-195, 2012.
Lupachev, A. V. and Abakumov, E. V.: Soils of Marie Byrd Land, West Antarctica, Eur. Soil Sci., 46, 994-1006, 2013.

Mergelov, N. S. and Goryachkin, S. V.: Soils and soil like bodies of Antarctica (the Larsemann Hills oasis), in Genesis, Geography, ad Classification of Soils and Inventory of Soil Resources, Conf. devoted to the 150th anniversary of the birth of N.M. Sibirtsev, Arkhangelsk, 38-42, 2010.

Mergelov, N. S., Goryachkin, S. V., Shorkunov, I. G., Zazovskaya, E. P., and Cherkinskii, A. E.: Endolithic pedogenesis and rock varnish on massive crystalline rocks in East Antarctica, Eur. Soil Sci. 45, 901-918, 2012.

Parnikoza, I., Korsun, S., Kozeretskaya, I., and Kunakh, V.: A discussion note on soil development under the influence of terrestrial vegetation at two distant regions of the Maritime Antarctic, Polarforchung, 80, 181-185, 2011.

Peter, H. U., Büßer, C., Mustafa, O., and Pfeiffer, S.: Risk assessment for the Fildes Peninsula and Ardley Island, and development of management plans for their designation as Specially Protected or Specially Managed Areas, Research Report 20313124 UBA-FB 001155e, Jena, Germany, 508, 2008.

Rinnan, R., Rousk, J., Yergeau, E., Kowalchuk, G. A., and Erland, B. A. A.: Temperature adaptation of soil bacterial communities along an Antarctic climate gradient: predicting responses to climate warming, Glob. Change Biol., 15, 2615-2625, 2009.

Simas, F. N. B., Schaefer, C. E. G. R., Melo, V. F., AlbuquerqueFilho, M. R., Michel, R. F. M., Pereira, V. V., Gomes M. R. M., and da Costa, L. M.: Ornithogenic Cryosols from Maritime Antarctica: Phosphatization as a soil forming process, Geoderma, 138, 191-203, 2007.

Simas, F. N. B., Schaefer, C. E. G. R., Albuquerque, F. M. R., Francelino, M. R., Filho, E. I. F., and da Costa, L. M.: Genesis, properties and classification of Cryosols from Admiralty Bay maritime Antarctica, Geoderma, 144, 116-122, 2008.

Smith, V. R.: Soil Respiration and its Determinants on a SubAntarctic Island, Soil Biol. Biochem., 35, 77-91, 2003.

Tedrow, J. F. C. and Ugolini, F. C.: Antarcic soils in: Antractic soils and soil forming processes, edited by: Tedrow, J. F. C., Washington, 161-177, 1966.

Ugolini, F. C. and Bockheim, J. G.: Antarctic soils and soils formation in a changing environment: A review, Geoderma, 144, 1-8, 2008.

Vance, E. D., Brookes, P. C., and Jenkinson, D. S.: An extraction method for measuring soil microbial biomass $\mathrm{C}$, Soil Biol. Biochem., 6, 703-707, 1987.

Vestal, R. J.: Biomass of the cryptoendolithic microbiota form the Antarctic desert, Appl. Env. Microbiol., 54, 957-959, 1988.

Vlasov, D. Yu., Abakumov, E. V., Nadporozhskaya, M. A., Kovsh, N. V., Krylenkov, V. A., Lukin, V. V., and Safronova, E. V.: Lithosols of King George Island, Western Antarctica, Eur. Soil Sci., 38, 681-687, 2005.

Walkley, A.: An examination of methods for determining organic carbon and nitrogen in soils, J. Agr. Sci., 25, 598-609, 1935.

Yoshitake, S., Uchida, M., Koizumi, H., and Nakatsubo, T.: Carbon and nitrogen limitation of soil microbial respiration in a High Arctic successional glacier foreland near Ny-Ålesund, Svalbard. Pol. Res., 26, 22-30, 2007.

Zhao, Ye.: The soil and environment in the Fildes Peninsula of Kind George Island, Antarctica, China, Bejing, 2000. 